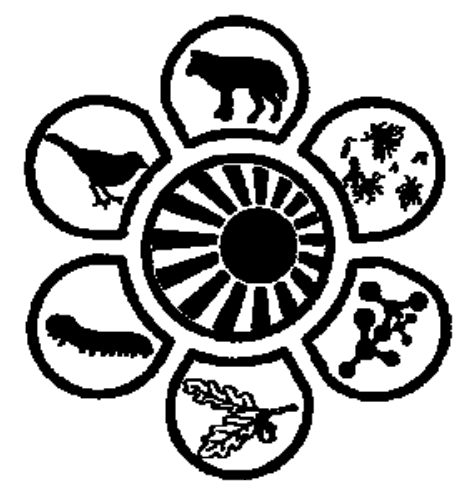

Вісник Дніпропетровського університету. Біологія, екологія.

Vìsnik Dnìpropetrovs'kogo unìversitetu. Seriâ Bìologiâ, ekologiâ

Visnyk of Dnipropetrovsk University. Biology, ecology.

Vìsn. Dnìpropetr. Unìv. Ser. Bìol. Ekol. 2014. 22(2), 105-109.

doi: $10.15421 / 011415$

ISSN 2310-0842 print

ISSN 2312-301X online

www.ecology.dp.ua

\title{
Вплив екскреторної функції ссавців на активність аспартатамінотрансферази в листках Glechoma hederacea в умовах забруднення кадмісм
}

\author{
О.М. Василюк, О.С. Пахомов \\ Дніпропетровський найіональний університет імені Олеся Гончара, Дніпропетровськ, Украӥна
}

Проаналізовано дослідження зі впливу $C d$ на активність ферменту азотного метаболізму аспартатамінотрансферази (АСТ, КФ 2.6.1.1) і вміст водорозчинної фракції білка (альбумінів) в листках Glechoma hederacea L., яка домінувала на дослідній теритоpiї (липово-ясенева діброва зі Stellaria holostea L.), де був внесений $C d$ у вигляді солі $C d\left(N_{3}\right)_{2}$ у спектрі концентрацій $0,25,1,25$ та 2,50 г/м ${ }^{2}$, що еквівалентно включенню $C d 1,5$ та 10 доз ГДК. 3'ясовано каталізацію $(P<0,05)$ активності АСТ у 2,6-3,0 рази (на фоні 1 та 5 ГДК) та вмісту альбумінів на 37\% (на фоні 10 ГДК) відносно контролю (ділянка без забруднення $C d$ та екскреторної функції ссавців). Залучення екскретів Capreolus capreolus L. сприяло нівелюванню токсичної дії Cd та відновленню функціонального метаболізму активності АСТ на $23 \%$ (на фоні $C d 1$ ГДК), на $34 \%$ ( $C d 5$ ГДК), що довело протекторну функцію ссавців та їх нівелювальний вплив в умовах даних концентрацій $C d$, тоді як за умов унесення максимальної дози $C d(10$ ГДК) активність АСТ була інгібована утричі, токсична дія металу екскреторною функцією ссавців не зменшувалась. Спостерігали нормалізацію вмісту альбумінів на 22\% відповідно в умовах $C d 1$ ГДК за умов унесення екскретів Capreolus capreolus L. та до контрольного рівня за умов унесення екскретів Sus scrofa L. на фоні $C d 10$ ГДК, що доводить необхідність використання представників ссавців для інтегрованої та всебічної нормалізації екосистем, порушених впливом важких металів.

Ключові слова: водорозчинна фракція білка; гранично допустима концентрація; аспартатамінотрансфераза

\section{Effect of mammals' excretory function on aspartate aminotransferase activity in Glechoma hederacea leaves in conditions of $\mathrm{Cd}$ pollution}

\author{
O.M. Vasilyuk, O.Y. Pakhomov \\ Oles Honchar Dnipropetrovsk National University, Dnipropetrovsk, Ukraine
}

\begin{abstract}
The paper includes analysis of research of $C d$ impact on the activity of the enzyme of aspartate aminotransferase (AST) nitrogen metabolism and the content of water-soluble protein fraction (albumin) in Glechoma hederacea L. leaves, which dominated in the research area (in natural floodplain oak forest with Stellaria holostea L.). $C d$ was introduced in the form of salts of $C d\left(N_{3}\right)_{2}$ in the range of concentrations of: $0.25,1.25$, $2.5 \mathrm{~g} / \mathrm{m}^{2}$, equivalent to the inclusion of $C d$ in $1,5,10$ doses of MAC. Increase $(\mathrm{P}<0.05)$ in the activity of AST 2.6-3.0 times (with adding $C d$ salts at a dose of 1 and $5 \mathrm{MAC}$ ) and albumin content by $37 \%$ (with adding $C d$ salts at a dose of $10 \mathrm{MAC}$ ) compared to control (the area without $C d$ pollution and excretory activity of mammals) was shown. Using of excreta of some representatives of mammals (for example, Capreolus capreolus L.) contributed to reduction of $C d$ toxic effects and restoring of the functional metabolic activity of AST by $23 \%$ (with $C d 1$ MAC) and by $34 \%$ ( $C d 5 \mathrm{MAC}$ ). It is the evidence of protective function of mammals and their normalization effect at the above concentrations of $C d$. Whereas the adding of $C d$ salts at a dose of 10 MAC led to 3 times' inhibition of AST activity, the toxic effect of metal by excretory function of mammals was not reduced. Observations revealed the albumin content normalization by $22 \%$ in the presence of $C d 1 \mathrm{MAC}$ respectively (with the introduction of $C$. capreolus excreta) and to the control level (the area without $C d$ pollution and excretory activity of mammals) with the excreta of Sus scrofa L. in the setting of Cd 10 MAC. It proves the need to use the different mammal species for integrated and comprehensive normalization of ecosystems under conditions of uncontrolled anthropogenic pollution.
\end{abstract}

Keywords: water-soluble protein fraction; maximum allowable concentration; aspartate aminotransferase

Дніпропетровський національний університет ім. Олеся Гончара, пр. Гагаріна, 72, Дніпропетровськ, 49010, Україна Oles' Honchar Dnipropetrovsk National University, Gagarin Ave., 72, Dnipropetrovsk, 49010, Ukraine

Tel.:+38-093-358-07-45. E-mail: vasilyuk.elena@mail.ru 


\section{Вступ}

Рослинні організми в умовах впливу антропогенних чинників зазнають певного ушкодження (Pakhomov and Vasilyuk, 2011). У літературі визначено ланку сприйняття та реакції на стрес. За дії екзогенного чинника відбувається розподіл $N O$ та саліцилової кислоти (СК) у напрямку: активні форми кисню - $\mathrm{NO}-\mathrm{CK}-\mathrm{H}_{2} \mathrm{O}_{2}-\mathrm{NO}$. Сполуки СК та абсцизової кислоти (АБК) активують ферменти антиоксидантного захисту (АОЗ) та окислювального стресу. Крім того, СК сприяє експресії генів, що контролюють активність протеїнових кіназ та МАП кіназ, чим забезпечують сигнальну стійкість систем (Musienko and Zhuk, 2009). Виявлено (Pandey et al., 2009) рівень окисного ушкодження іонів згідно з порядком: $N i>$ $C o>C d>C u>Z n$ y Spinacia oleracea L., виявлено зміни діяльності AO3 та перекисного окислення ліпідів (ПОЛ) у проростках пшениці за дії $P b$ i $C d$ (Dey et al., 2007), з'ясовано дію $Z n$ на синтез триптофану, сумарних амінокислот і розчинних білків (Malta et al., 2002) у Coffea arabica L. Екзогенним додаванням $\mathrm{NO}_{2}^{-}$досліджувався вплив даних іонів на активність нітрат-редуктаз, ферментів первинного метаболізму, в Anacardium occidentale L. (Viegas and Silvera, 2002).

Визначено структурні зміни, викликані $Z n$ і $C d$ у Hordeum vulgare, та співвідношення важких металів (BM) 3 анатомічними, фізіологічними та морфологічними змінами у рослин (Sridhar, 2007). Вивчено механізми детоксикації сполук Cu у Crassula helmsii (Kirk) Cockayne, акумулятора $C u$ (Küpper, 2009). У літературі $\epsilon$ дані стосовно порівняння механізмів детоксикації $C u$ i $C d$ у чутливих до цих елементів гіперакумуляторних рослин Thlaspi caerulescens (Mijovilovich et al., 2009), порівняно (Mesjasz-Przybyłowicz et al., 2007) механізми цитологічного розподілу $N i$ коренями гіперакумуляторів і негіперакумуляторів генотипів Senecio coronatus (Thunb.) Harv. досліджено базові механізми фізіологічної, молекулярної та генетичної можливості накопичення ВМ гіперакумуляторами (Kramer, 2010). Виявлено просторову організацію клітинної стінки та зміни реакцій метил-етерифікації гомогалактуронів на $C d$-індукований стрес (Douchiche et al., 2010), з'ясовано обмін речовин рослин в умовах високої концентрації $\mathrm{Al}, \mathrm{Cu}, \mathrm{La}$ (Kopittke et al., 2008).

У коренях, пагонах і насінні Thlaspi praecox Wulfen, Brassica napus L. та Arabidopsis thaliana (L.) Hеynh. вивчено транспорт есенціальних металів ( $F e, Z n, M n$ i $C u)$ i транспорт, толерантність, вакуолярну послідовність та рівень транскрипційних реакцій за умов дії неесенціальних металів ( $C d, P b, C r, H g$ і $A s)$, їх токсичність на рослинний гомеостаз (Mendoza-Cózatl et al., 2011; Song et al., 2010; Takamatsu et al., 2010). Визначено вплив $C r, C d$ та $P b$ на середземноморські грунти (Martí et al., 2013) через біодоступність $C d, P b$ та $Z n$ та через атмосферні емісії $C d$ та $P b$ (Roussel et al., 2010), визначено рослинний метаболізм під впливом $\mathrm{Cd}$, Co, $\mathrm{Mn}, \mathrm{Cr}$ (Hameed et al., 2011; Hasan et al., 2011; Ruscitti et al., 2011; Vestena et al., 2011; Becerril et al., 2013; Lefcort et al., 2013; Millaleo et al., 2013).

Ми вивчали $C d$ як токсичний елемент, один з основних полютантів довкілля. Водночас, $C d$ належить до групи «нових» мікроелементів $(C d, V, S i, S n, F)$, за низь- ких концентрацій $C d$ здатний стимулювати ріст деяких тварин, але його дія на вищі рослини достовірно не 3'ясована, фізіологічна роль вивчена недостатньо. $C d$ знайдено у складі «металотіонеїну» - білка, для якого характерний високий вміст сульфгідрильних груп та ВМ. Функція тіонеїну полягає у зв'язуванні та транспорті ВМ та їх детоксикації. In vitro $C d$ активує декілька $Z n$ залежних ферментів: триптофаноксигеназу, ДАЛКдегідратазу, карбоксипептидазу. Однак ферментів, які б активувались винятково $C d$, не виявлено. На всмоктування $C d$ суттєво впливає наявність інших біоелементів $(\mathrm{Ca}, \mathrm{Zn}, \mathrm{Cu})$, харчових волокон тощо.

Середовищетвірна активність тварин - важливий чинник в умовах антропогенного впливу на довкілля. Екологічні послуги ссавців дають можливість для відновлення, збереження біорізноманіття, урегулювання довкілля (Bulakhov et al., 2003; Vasilyuk and Pakhomov, 2012, 2014). У даній роботі індикацію дії антропогенних чинників із використанням екосистемних послуг зоокомпонентів Sus scrofa L. та Capreolus capreolus L. проводили з використанням біохімічних індикаторів ферментів азотного метаболізму та вмісту альбумінів.

\section{Матеріал і методи досліджень}

Досліди проводили в умовах Присамарського міжнародного біосферного стаціонару ім. О.Л. Бельгарда. Як контроль обрано територію, не забруднену $C d$ (липово-ясенева діброва із зірочником ланцетолистим (Stellaria holostea L.) та в умовах забруднення грунтів солями $C d$. Кадмій вносили у грунт у вигляді $C d\left(N_{3}\right)_{2}$ у спектрі концентрацій $0,25,1,25$ та $2,50 \quad \Gamma / \mathrm{m}^{2}$, що еквівалентно 1, 5 та 10 доз ГДК Сd відповідно. Для запобігання забруднення шарів грунту $C d$ використано ізольовані грунтові блоки (глибина $20 \mathrm{~cm}$ ). Під час внесення враховували кількість ГДК для $C d$ (5 мг/кг грунту). Визначено загальну (Polevoy and Maximov, 1978) активність аспартатамінотрансферази (АСТ, КФ 2.6.1.1; нМ піровиноградної кислоти/мл·с) і концентрацію (мг/мл) водорозчинної фракції білка (Bradford, 1976) як індикаторів екологічного стану довкілля. АСТ й аланінамінотрансфераза (АЛТ, КФ 2.6.1.2) є частиною ферментативної системи, за допомогою якої утилізується первинний продукт фотосинтезу $\mathrm{C}_{4}$-групи рослин аспартат, який синтезується у мезофілі листка та направляється до клітин обкладинки судинних пучків (Polevoy and Maximov, 1978). За допомогою АCТ у клітинах обкладинки судинних пучків листка відбувається декарбоксилювання аспартату, що утворився в мезофілі листка, до піровиноградної кислоти та діоксиду вуглецю. Піруват амінується за допомогою АЛТ до аланіну та повертається до мезофілу листка, де дезамінується за участі того самого АЛТ. У роботі достовірною вважали відмінність між дослідним варіантом та контролем за $\mathrm{P}<0,05$. Для кожного варіанта експерименту $\mathrm{n}=3$.

Біохімічні показники визначали через місяць у листках Glechoma hederacea L., що домінувала на даній території, за такою схемою:

1) монодія: контроль (ділянка без забруднення $C d$ та екскременти ссавців), дослід $C d 1,5$ та 10 ГДК; 
2) комбінована дія: контроль (ділянка без забруднення $C d$ та екскременти ссавців), контроль $C d 1$ ГДК, вплив $C d 1$ ГДК на фоні дії екскрементів $S$. scrofa, вплив $C d 1$ ГДК на фоні екскрементів C. capreolus, контроль $C d 5$ ГДК, вплив $C d 5$ ГДК на фоні дії екскрементів S. scrofa, вплив $C d 5$ ГДК на фоні дії екскрементів C. capreolus, контроль $C d 10$ ГДК, вплив $C d 10$ ГДК на фоні дії екскрементів $S$. scrofa, вплив $C d 10$ ГДК на фоні дії екскрементів C. capreolus.

\section{Результати та їх обговорення}

Визначено достовірне $\left(\mathrm{t}_{0,05}=1,98\right.$ та 2,80$)$ підвищення активності АСТ в листках $G$. hederacea у 2,6-3,2 раза при збільшенні концентрації $C d$ від 1 до 5 ГДК відносно контролю (ділянка без забруднення $C d$ та екскреторної функції ссавців). Збільшення концентрації $C d$ до максимальної (10 ГДК) сприяло недостовірному $\left(\mathrm{t}_{0,05}=\right.$ $0,27)$ зниженню активності ферменту. Вміст водорозчинної фракції білків достовірно зменшувався $\left(\mathrm{t}_{0,05}=1,64\right.$, 1,96 та 2,41) при внесенні $C d$ у дозі 1 та 5 ГДК і становив $72-80 \%$ відносно контролю (ділянка без забруднення $C d$ та екскрементів ссавців). Додавання $C d$ у дозі 10 ГДК сприяло значному (на 37\%) зростанню концентрації альбумінів у листках $G$. hederacea (табл. 1).

Таблиия 1

Вплив $\boldsymbol{C d}$ на активність аспартатамінотрансферази та концентрацію водорозчинної фракції білків у листках Glechoma hederacea $\mathbf{L}$.

\begin{tabular}{|c|l|c|c|}
\hline Показники & $\begin{array}{c}\text { Варіанти } \\
\text { досліду }\end{array}$ & $\mathrm{x} \pm \mathrm{SD}$ & $\begin{array}{c}\text { Співвідношення } \\
\text { дослід/контроль, \% }\end{array}$ \\
\hline \multirow{2}{*}{$\begin{array}{c}\text { Активність } \\
\text { aспартатаміно- }\end{array}$} & Контроль & $0,88 \pm 0,089$ & 100,0 \\
\cline { 2 - 4 } трансферази & $C d$ ГДК & $2,33 \pm 0,391^{*}$ & 266,2 \\
\cline { 2 - 4 } & $C d$ ГДК & $2,79 \pm 0,359^{*}$ & 317,6 \\
\hline \multirow{3}{*}{$\begin{array}{c}\text { Водорозчинна } \\
\text { фракція білка }\end{array}$} & Контроль & $0,81 \pm 0,114$ & 91,9 \\
\cline { 2 - 4 } & $C d 1$ ГДК & $1,82 \pm 0,115$ & 100,0 \\
\cline { 2 - 4 } & $C d$ ГДК & $1,33 \pm 0,035^{*}$ & 80,2 \\
\cline { 2 - 4 } & $C d 10$ ГДК & $2,50 \pm 0,103^{*}$ & 72,9 \\
\hline
\end{tabular}

Примітки: * - достовірність відмінності між дослідним варіантом і контролем $\mathrm{P}<0.05$; для кожного варіанта досліду - триразова повторність.

За комбінованої дії екскретів ссавців і $C d$ визначено достовірне $\left(\mathrm{t}_{0,05}=2,91\right.$ та 1,98$)$ підвищення відносно контролю (ділянка без забруднення $C d$ та екскретів ссавців) активності АСТ у листках G. hederacea на $177 \%$ (S. scro$f a)$ на фоні внесення $C d 1$ ГДК та на $151 \%$ (C. capreolus). При збільшенні навантаження до $C d 5$ ГДК комбінована дія чинників сприяла достовірному підвищенню $\left(\mathrm{t}_{0,05}=\right.$ 9,92 та 2,35) нітратного обміну на 164-200\% відносно контролю (ділянка без забруднення $C d$ та екскретів ссавців). При збільшенні екзогенного навантаження на біоту (Cd 10 ГДК) спостерігали інгібування $\left(\mathrm{t}_{0,05}=2,30\right.$ та $1,68)$ нітратного обміну на $69-71 \%$ на фоні екскретів ссавців (табл. 2).

В умовах комбінованої дії біотичних і антропогенних чинників змінювалась також концентрація водорозчинної фракції білка в листках G. hederacea. При внесенні Cd 1 ГДК на фоні дії екскреторної активності ссавців відбулось коливання (зниження чи підвищення) нітрат- ного обміну таким чином, що екскременти C. capreolus сприяли відновленню АСТ до контрольних показників, відмінності між дослідним варіантом і контролем не були достовірними $\left(\mathrm{t}_{0,05}=0,10\right)$.

Таблиия 2

Вплив комбінованої дії екскреторної функції ссавців i $\boldsymbol{C d}$ на активність аспартатамінотрансферази в листках Glechoma hederacea $\mathrm{L}$.

\begin{tabular}{|l|l|c|}
\hline \multicolumn{1}{|c|}{ Варіанти досліду } & $\mathrm{x} \pm \mathrm{SD}$ & $\begin{array}{c}\text { Співвідношення } \\
\text { дослід / контроль, } \%\end{array}$ \\
\hline Контроль & $0,88 \pm 0,089$ & 100,0 \\
\hline Контроль $C d 1$ ГДК & $2,23 \pm 0,390^{*}$ & 266,2 \\
\hline S. scrofa $+C d 1$ ГДК & $2,43 \pm 0,276^{*}$ & 277,0 \\
\hline C. capreolus $+C d 1$ ГДК & $2,20 \pm 0,478^{*}$ & 251,4 \\
\hline Контроль $C d 5$ ГДК & $2,79 \pm 0,359^{*}$ & 317,6 \\
\hline S. scrofa $+C d 5$ ГДК & $2,63 \pm 0,035^{*}$ & 300,0 \\
\hline C. capreolus $+C d 5$ ГДК & $2,32 \pm 0,322^{*}$ & 264,9 \\
\hline Контроль $C d 10$ ГДК & $0,81 \pm 0,114$ & 91,9 \\
\hline S. scrofa $+C d 10$ ГДК & $0,34 \pm 0,088^{*}$ & 31,2 \\
\hline C. capreolus $+C d 10$ ГДК & $0,26 \pm 0,179^{*}$ & 29,7 \\
\hline
\end{tabular}

Примітка: див. табл. 1.

Підвищення вмісту металу до $C d 5$ ГДК, застосування екскрементів як S. scrofa, так і C. capreolus сприяло відновленню нітратного метаболізму, наближаючи до контрольного $\left(\mathrm{t}_{0,05}=2,09\right.$ та 2,10), порівняно 3 монодією (тільки кадмій). Підвищення концентрації металу до 10 ГДК та екскреторна активність S. scrofa порівняно 3 C. capreolus сприяли відновленню вмісту альбумінів до контрольного $\left(\mathrm{t}_{0.05}=3,59\right)$, тоді як $C$. capreolus не нівелював токсичну дію нікелю за даних концентрацій $\left(\mathrm{t}_{0,05}=3,59\right)$. Це довело більшу ефективність протекторної дії $C$. capreolus порівняно з $S$. scrofa за низьких і середніх концентрацій нікелю при відновленні вмісту альбумінової фракції (табл. 3). Спостерігали кореляцію $(\mathrm{r}=0,86)$ між активністю АСТ та вмістом альбумінів в умовах монодії $C d$ у спектрі концентрацій.

\section{Вплив комбінованої дії екскрементів ссавців та $\boldsymbol{C d}$ на вміст білків водорозчинної фракції в листках Glechoma hederacea $\mathrm{L}$.}

\begin{tabular}{|l|l|c|}
\hline \multicolumn{1}{|c|}{ Варіанти досліду } & \multicolumn{1}{c|}{$\mathrm{X} \pm \mathrm{S}_{\mathrm{x}}$} & $\begin{array}{c}\text { Співвідношення } \\
\text { дослід / контроль, } \%\end{array}$ \\
\hline Контроль & $1,76 \pm 0,011$ & 100,0 \\
\hline Контроль $C d 1$ ГДК & $1,49 \pm 0,021^{*}$ & 84,9 \\
\hline S. scrofa $+C d 1$ ГДК & $1,35 \pm 0,005^{*}$ & 76,6 \\
\hline C. capreolus $+C d 1$ ГДК & $1,88 \pm 0,641$ & 107,0 \\
\hline Контроль $C d 5$ ГДК & $1,15 \pm 0,382$ & 65,4 \\
\hline S. scrofa $+C d 5$ ГДК & $1,32 \pm 0,115^{*}$ & 74,3 \\
\hline C. capreolus $+C d 5$ ГДК & $1,37 \pm 0,098^{*}$ & 78,1 \\
\hline Контроль $C d 10$ ГДК & $2,54 \pm 0,118^{*}$ & 144,5 \\
\hline S. scrofa $+C d 10$ ГДК & $1,65 \pm 0,165$ & 93,8 \\
\hline C. capreolus $+C d 10$ ГДК & $1,37 \pm 0,165^{*}$ & 77,8 \\
\hline
\end{tabular}

Примітка: див. табл. 1.

\section{Висновки}

В умовах комбінованої дії $C d$ та екскрементів C. capreolus активність АCТ на фоні $C d 1$ ГДК знижувалася на $14 \%$, на фоні $C d 5$ ГДК - на $53 \%$, на фоні $C d$ 
10 ГДК - утричі. Екскреторна активність $S$. scrofa сприяла підвищенню активності АСТ з 266\% до 277\% на фоні $C d 1$ ГДК, зниженню на $17 \%$ на фоні $C d 5$ ГДК, удвічі на фоні $C d 10$ ГДК.

3'ясовано каталізацію $(P<0.05)$ активності АCТ у 2,6-3,0 раза (на фоні 1 та 5 ГДК) та вмісту альбумінів на 37\% (на фоні 10 ГДК) відносно контролю (ділянка без забруднення $C d$ та екскреторної функції ссавців). Залучення екскретів $C$. capreolus сприяло нівелюванню токсичної дії $C d$ та відновленню функціонального метаболізму активності АСТ на 23\% (на фоні Cd 1 ГДК), на 34\% (Cd 5ГДК), що довело протекторну функцію ссавців та їх нівелювальний вплив в умовах даних концентрацій $C d$, тоді як за умов унесення максимальної дози $C d$ (10 ГДК) активність АСТ була інгібована утричі, токсична дія металу екскреторною функцією ссавців не зменшувалась. Спостерігали нормалізацію вмісту альбумінів на $22 \%$ відповідно в умовах $C d 1$ ГДК за умов унесення екскретів $C$. capreolus і до контрольного рівня за умов унесення екскретів $S$. scrofa на фоні $C d 10$ ГДК, що доводить необхідність використання представників ссавців для інтегрованої та всебічної нормалізації екосистем, порушених впливом важких металів.

\section{Бібліографічні посилання}

Becerril, F.R., Juárez-Vázquez, L.V., Hernández-Cervantes, S.C., Acevedo-Sandoval, O.A., Vela-Correa, G., CruzChávez, E., Moreno-Espíndola, I.P., Esquivel-Herrera, A., de León-González, F., 2013. Impacts of manganese mining activity on the environment interactions among soil, plants and arbuscular mycorrhiza. Arch. Environ. Contam. Toxicol. 64(2), 219-227.

Bradford, M., 1976. A rapid and sensitive method for the quantification of microgram quantities of protein utilising the principle of protein-dye binding. Anal. Biochem. (72), 248-254.

Bulakhov, V.L., Emel'janov, I.G., Pakhomov, O.Y., 2003. Bioraznoobrazie kak funkcional'naja osnova jekosistem [Biodiversity as functional basis of ecosystems]. Vìsn. Dnìpropetr. Unìv. Ser. Bìol. Ekol. 11(1), 3-8.

Dey, S.K., Dey, J., Patra, S., Pothal, D., 2007. Changes in the antioxidative enzyme activities and lipid peroxidation in wheat seedlings exposed to cadmium and lead stress. Braz. J. Plant Physiol. 19(1), 53-60.

Douchiche, O., Driouich, A., Morvan, C., 2010. Spatial regulation of cell-wall structure in response to heavy metal stress: Cadmium-induced alteration of the methyl-etherification pattern of homogalacturonans. Ann. Bot. (Lond.) 105, 481-491.

Hameed, A., Mahmooduzzafar, T.N.Q., Siddiqi, T.O., Iqbal, M., 2011. Differential activation of the enzymatic antioxidant system of Abelmoschus esculentus L. under $\mathrm{CdCl}_{2}$ and $\mathrm{HgCl}_{2}$ exposure. Braz. J. Plant Physiol. 23(1), 46-54.

Hasan, S.A., Hayat, S., Wani, A.S, Ahmad, A., 2011. Establishment of sensitive and resistant variety of tomato on the basis of photosynthesis and antioxidative enzymes in the presence of cobalt applied as shotgun approach. Braz. J. Plant Physiol. 23(3), 175-185.

Kopittke, P.M., Blamey, F.P.C., Menzies, N.W., 2008. Toxicities of soluble $\mathrm{Al}, \mathrm{Cu}$, and $\mathrm{La}$ include ruptures to rhizodermal and root cortical cells of cowpea. Plant Soil 303, 217-227.

Kramer, U., 2010. Metal hyperaccumulation in plants. Annu. Rev. Plant Biol. 61, 517-534.

Küpper, H., Götz., B., Mijovilovich, A., Küpper, F.C., MeyerKlaucke, W., 2009. Complexation and toxicity of copper in higher plants. I. Characterization of copper accumulation, speciation, and toxicity in Crassula helmsii as a new copper accumulator. Plant Physiol. 151, 702-714.

Lefcort, H., Wehner, E.A., Cocco, P.L., 2013. Look inside get access pre-exposure to heavy metal pollution and the odor of predation decrease the ability of snails to avoid stressors. Arch. Environ. Contam. Toxicol. 64(2), 273-280.

Malta, M.R., Furtinineto, A.E., Alves, J.D., Guimaraes, P.T.G., 2002. Effect of zinc application on tryptophan synthesis, total amino acids and total soluble proteins of leaves of coffee seedlings. Braz. J. Plant Physiol. 14(1), 31-37.

Martí, E., Sierra, J., Cáliz, J., Montserrat, G., Vila, X., Garou, M.A., Cruañas, R., 2013. Ecotoxicity of $\mathrm{Cr}, \mathrm{Cd}$, and $\mathrm{Pb}$ on two mediterranean soils. Arch. Environ. Contam.Toxicol. 64(3), 377-387.

Maruthi Sridhar, B.B., Han, F.X., Diehl, S.V., Monts, D.L., Su, Y., 2007. Effects of $\mathrm{Zn}$ and $\mathrm{Cd}$ accumulation on structural and physiological characteristics of barley plants. Braz. J. Plant Physiol. 19(1), 15-22.

Mendoza-Cózatl, D.G., Jobe, T.O., Hauser, F., Schroeder, J.I., 2011. Long-distance transport, vacuolar sequestration, tolerance, and transcriptional responses induced by cadmium and arsenic. Curr. Opin. Plant Biol. 14(5), 554-562.

Mesjasz-Przybyłowicz, J., Barnabas, A., Przybyłowicz, W., 2007. Comparison of cytology and distribution of nickel in roots of Ni-hyperaccumulating and non-hyperaccumulating genotypes of Senecio coronatus. Plant Soil 293, 61-78.

Mijovilovich, A., Leitenmaier, B., Meyer-Klaucke, W., Kroneck, P.M.H., Götz, B., Küpper, H., 2009. Complexation and toxicity of copper in higher plants. II. Different mechanisms for copper versus cadmium detoxification in the copper-sensitive cadmium/zinc hyperaccumulator Thlaspi caerulescens (Ganges ecotype). Plant Physiol. 151, 715-731.

Millaleo, R., Reyes-Díaz, M., Alberdi, M., Ivanov, A.G., Krol, M., Hüner, N.P.A., 2013. Excess manganese differentially inhibits photo system I versus II in Arabidopsis thaliana L. J. Exp. Bot. 64(91), 343-354.

Musienko, M.M., Zhuk, I.V., 2009. Molekulyarni mehanizmi induktsiyi zahisnih reaktsiy roslin $\mathrm{v}$ umovah posuhi [Molecular mechanisms of induction of defense reactions of plants in drought conditions]. Ukr. Bot. J. 66(4), 580-595 (in Ukrainian).

Pakhomov, O.E., Vasilyuk, O.M., 2011. Activity of transamination enzyme as the indicater of biological revegetation of soils Mammalia in transformed ecosystems. The abstracts NATO advanced research workshop (ARW): Environmental security for South-East Europe and Ukraine. NATO Science Series book, Dnipropetrovsk. pp. 74-75.

Pandey, N., Pathak, G.C., Pandey, D.K., Pandey, R., 2009. Heavy metals, $\mathrm{Co}, \mathrm{Ni}, \mathrm{Cu}, \mathrm{Zn}$ and $\mathrm{Cd}$, produce oxidative damage and evoke differential antioxidant responses in spinach. Braz. J. Plant Physiol. 21(2), 103-111.

Polevoy, V., Maximov, G. (eds.), 1978. Metody biohimicheskogo analiza rastenij [Methods of analysis biochemically of plants]. Leningrad University Press, Leningrad (in Russian).

Roussel, H., Waterlot, C.A., Pelfrêne, A., Pruvot, C., Mazzuca, M., Douay, F., 2010. Cd, $\mathrm{Pb}$ and $\mathrm{Zn}$ oral bioaccessibility of urban soils contaminated in the past by atmospheric emissions from two lead and zinc smelters. Arch. Environ. Contam. Toxicol. 58(4), 945-954.

Ruscitti, M., Arango, M., Ronco, M., Beltrano, J., 2011. Inoculation with mycorrhizal fungi modifies proline metabolism and increases chromium tolerance in pepper plants (Capsicum annuum L.). Braz. J. Plant Physiol. 23(1), 15-25.

Song, W.Y., Park, J., Mendoza-Cózatl, D.G., Suter-Grotemeyer, M., Shim, D., Hörtensteiner, S., Geisler, M., Weder, B., Rea, P.A., Rentsch, D., Schroeder, J.I., Lee, Y., Martinoia, E., 2010. Arsenic tolerance in Arabidopsis is mediated by two 
ABCC-type phytochelatin transporters. Proc Natl. Acad. Sci. USA. 107, 21187-21192.

Takamatsu, T., Murata, T., Koshikawa, M., Watanabe, M., 2010. Weathering and dissolution rates among $\mathrm{Pb}$ shot pellets of differing elemental compositions exposed to various aqueous and soil conditions. Arch. Environ. Contam. Toxicol. 59(1), 91-99.

Vasilyuk, O.M., Pakhomov, A.E., 2014. Effect of lead ions on alanine aminotransferase activity in Glechoma hederacea leaves subject. Scientific enquiry in the contemporary world: Theoretical basics and innovative approach. Ser. Natural sciences. Ed. 2d. Research articles. B\&M Publishing San Francisco, California, USA, B\&M Publishing Research and Publishing Center "Colloquium". 1, 19-26.

Vasilyuk, O.M., Pakhomov, O.E., 2012. Vplyvi ioniv nikelju na funkcional'nu aktyvnist' transaminaz v lystkah Glechoma hederatia L. v umovah ryjnoi' aktyvnosti Mammalia [Effect of nickel ions on the functional activity of enzymes in the leaves of Glechoma hederatia L. in digging activity of Mammalia]. Achievement of High school - 2012: Materialy VIII Mezhdunarodnoj Nauchno-Prakticheskoj Konferencii. Bjal GRAD-BG, Sofija, Bolgarija, 21, $43-49$ (in Ukrainian). Vestena, S., Cambraia, J., Ribeiro, C., Oliveira, J.A., Oliva, M.A., 2011. Cadmium induced oxidative stress and antioxidative enzyme response in water hyacinth and salvinia. Braz. J. Plant Physiol. 23(2), 131-139.

Viegas, R.A., Silveira, J.A.G., 2002. Activation of nitrate reductase of cashew leaf by exogenous nitrite. Braz. J. Plant Physiol. 14(1), 39-44.

Надійшла до редколегії 12.07.2014 